\title{
Optimizing insurance pricing by incorporating consumers' perceptions of risk classification
}

\author{
Tina Störmer
}

Published online: 16 December 2014

(C) Springer-Verlag Berlin Heidelberg 2014

\begin{abstract}
Insurers primarily set premiums using cost-oriented pricing methods based on claims history. Customer-oriented pricing has yet to be widely applied. This article empirically tests consumers' acceptance of (currently unused) risk characteristics in motor and term life insurance pricing in the United Kingdom, France, and Germany. We derive implications concerning how insurers' can use the knowledge of consumer acceptance or rejection of specific price-determining factors when standardizing their pricing schemes. The results indicate that consumers highly approve commonly used risk-rating factors when their price-determining function is transparent. Furthermore, consumers are willing to provide insurance companies further personal information when such information is used for pricing. The provision of personal information allows insurance companies to conduct a critical review of attributes requested and used that have a low impact on premium amounts and lower consumer acceptance ${ }^{1}$.
\end{abstract}

JEL Classification C93 $\cdot \mathrm{E} 21 \cdot \mathrm{G} 22$

\section{Introduction}

The current volatile economic and political environment represents a major challenge for the insurance industry (Seiler et al. 2013, p. 1). The highly competitive market

\footnotetext{
${ }^{1}$ This paper was written during the author's $\mathrm{PhD}$ studies and its time as project manager at the Institute of Insurance Economics at the University of St. Gallen, Switzerland.
}

T. Störmer $(\square)$

Zurich University of Applied Sciences,

Technoparkstrasse 2,

8401 Winterthur, Switzerland

e-mail: stot@zhaw.ch 
has turned out to be characterized by cost pressure (Capgemini and Efma 2013, p. 8). The saturation of the European insurance markets can be seen in the $-2.0 \%$ total premium volume decrease that occurred in Western Europe in $2011(-5.9 \%$ in 2010 , Seiler et al. 2013, p. 33). A similar picture is emerging in the three largest European insurance industries, namely, the United Kingdom (U.K.), France, and Germany. While in the U.K. (-2.1\%) and France $(-5.5 \%)$ premium volumes decreased, the German insurance market recorded slight growth of $0.3 \%$ (Seiler et al. 2013, p. 35). Although premium declines have reduced in the last year, however, premium levels have not returned to their pre-crisis levels (Seiler et al. 2013, p. 20).

In addition, insurance companies undertook internal consolidation and optimizing processes over previous years, mainly in response to external conditions such as regulatory requirements and the incorporation of new technologies (Schmidt-Gallas and Beeck 2007, p. 7). Consequently, business processes as well as administrative and distribution costs are already largely optimized (Schmidt-Gallas and Beeck 2007, p. 7). To examine how future earnings, growth, and competitive advantage can be generated (Gard and Eyal 2012, p. 1), the adequacy and refinement of insurers' current pricing structure is a topic of much debate. Studies show that price management will, in the coming years, take on new importance for the insurance industry (Schmidt-Gallas and Beeck 2007; Scherer and Schmeiser 2010; Simon Kucher \& Partners 2011a, c; Gard and Eyal 2012; RGA and Towers Watson 2013).

Existing pricing methods and strategies are based on established economic principles of cost-oriented insurance operations (IBM Global Business Services 2006, p. 2). However, these existing pricing processes are evolving because of recent legal, ${ }^{2}$ political, and economic conditions, on the one hand, and of scientific progresses in medical, technical, and information sciences (Actuarial Standards Board 2005, p. 9). In addition, changing consumer needs also influence pricing structure. The current pricing process is highly cost-oriented, with $75 \%$ of insurance companies having a strong actuarial pricing focus based on risk costs (Gard and Eyal 2012, p. 3). This high proportion indicates that actuarial pricing is expected to remain standard industry practice. However, to generate profitable future growth, managers attach great importance to the possibility of customer-oriented pricing (Schmidt-Gallas and Beeck 2007, p. 7), a pricing method that incorporates consumers' willingness to pay as well as consumer group segmentation (Gard and Eyal 2012, p. 3).

This study aims to analyze current pricing practices in Europe to discuss how additional future growth can be generated in saturated markets. This analysis considers continued technological change and newly developed customer preferences that drive insurance demand. We provide background information regarding insurers' pricing practices based on risk classification. We also consider individual consumer needs and their perception of price determination within the insurance industry as part of discussing opportunities and challenges associated with customer-specific pricing.

\footnotetext{
${ }^{2}$ From a regulatory viewpoint, for example, the judgment of the European Court of Justice (ECJ) led to an adjustment of existing underwriting on March 1, 2011 introducing a ban on the use of the gender criterion in insurance pricing. Because of the court's decision, insurance companies had to offer unisex premiums from December 21, 2012 onwards in the European Union (EU, ECJ 2010, p. 7). In this specific context, the question arose whether current risk-based pricing methods are adequate.
} 
To prove whether customer-oriented pricing is applicable in an insurance context, we ask customers themselves of their opinion regarding insurance pricing. The study reports on an international consumer survey conducted over 1500 questionnaires answered in the U.K., France, and Germany. The poll is used to analyze consumers' acceptance of currently used risk factors and their readiness to offer insurers further information revealing personal price-determining characteristics in the context of receiving a price for motor and term life insurance. In particular, the study addresses the following questions. First, which personal price-determining risk characteristics requested by insurers do customers find acceptable? Second, do consumers recommend the use of such information in determining premiums? To identify respondents' preferences, we use descriptive statistics, reporting on the average appreciation rating for various risk characteristics as well as the average standard deviation for each product line and each country. The results indicate differences in consumers' degree of acceptance between countries as well as across product lines. In addition, a high degree of acceptance of commonly used price-determining factors can be observed across all countries and product lines, but only when the use of such factors is comprehensible and transparent to customers. Knowing consumers' preferences regarding accepted price-determining factors enables insurers to calibrate their pricing models to best meet consumer price expectations. Furthermore, implications for price communication can be derived. Consumers' understanding of the insurance pricing process can be increased by improving the transparency of current practices (Störmer and Wagner 2013, p. 21). If less complicated and more comprehensible insurance policies can be provided, consumers' consumption costs will be reduced (Abraham 1985, p. 417).

The remainder of the study is structured as follows. Next, we provide a review of relevant literature. In Sect. 2, we analyze insurance pricing practices in Europe. Sect. 2.1 provides an overview of Europe's three largest insurance markets. In Sect. 2.2, we consider the theory of risk differentiation as applied by the insurance pricing process for motor and term life insurance. In Sect. 3, first, we describe the recent international consumer survey (Sect. 3.1). Second, we present our results for each country and each product line (Sect. 3.2). We summarize the main findings in Sect. 3.3. In Sect. 4, we discuss the results of our analysis with a focus on the implications for adjustment to current pricing schemes and strategic price communication. Finally, Sect. 5 presents our conclusions and future research implications.

Literature review. The facets of actuarial pricing are described in detail in the scientific literature. The economic relevance and welfare implications of cost-oriented risk-based insurance pricing have often been analyzed in detail (Arrow 1963; Rothschild and Stiglitz 1976; Hoy 1982; Borch 1984; Crocker and Snow 1986; Powers 2010). As one of the first authors, Williams (1957) views the method of economical price discrimination in light of insurance pricing and takes regulatory requirements into account. Doherty analyzes market conditions that can prove profitable for an insurer to differentiate risks between various groups (Doherty 1980, 1981, 1983). Abraham (1985, p. 403) identifies risk classification and setting prices based on such classifications as "the heart of any insurance system." As risk classifications grow more efficient, information asymmetries decrease. Several authors who deal with 
this issue state that risk classification can prevent adverse selection (Rothschild and Stiglitz 1976; Hoy 1982; Abraham 1985).

In addition to economic effects, many authors analyze the consequences of regulatory decisions upon risk-based pricing (Venezian 1984; De Wit 1986; Crocker and Snow 1986, 2000; Hoy 2006; Thiery and Van Schoubroeck 2006; Thomas 2007, 2008). Abraham (1985) argues that the consequences of risk classification include moral issues. He considers that different loss expectations because of different risk types justify variations in insurance premiums between individuals. However, insurance also collectively covers risks in the event that a member of a risk group suffers a loss. Conflicts emerge between these two levels of risk when the probability of loss occurrence and the size of possible losses depend on variables that "have unacceptable social or moral connotations" (Abraham 1985, p. 406), e.g., policyholder nationality or gender. Walters (1981) defines standards to incorporate the regulatory aspect requiring insurance premiums not to be imposed on an unfairly discriminatory basis. Therefore, risk classification is mainly based on "homogeneous, well-defined, and practical" characteristics (Walters 1981, p. 1).

Public and scientific discussions regarding fair risk classification in Europe emerged following the 1980s ban on "foreigner" being considered a risk factor (Schwarze and Wein 2005, p. 175). ${ }^{3}$ The adoption of Council Directive 2004/113/EC again prompted questions regarding the adequacy of several risk-rating factors used in underwriting (Buzzacchi and Valletti 2005; Thiery and Van Schoubroeck 2006).

These discussions have also driven analyses seeking to enhance currently used risk-rating factors. For risk classification in life insurance, various studies examine the relevance of genetic health risks and the use of genetic tests for insurance pricing (Christianson 1996; Brockett et al. 1999; Hoy and Lambert 2000; Morris 2010; Durnin et al. 2012). ${ }^{4}$ Furthermore, the link between life expectancy and health consciousness has been increasingly discussed (Hambrecht et al. 2000; Fillenbaum et al. 2007; Pell et al. 2008; Löllgen and Löllgen 2009; Löllgen et al. 2009; Ford et al. 2011; Behrens et al. 2013). Löllgen and Löllgen (2009) indicate that common diseases such as cardiovascular diseases often reflect an unhealthy lifestyle. Their development and progression can be mitigated and mortality can be reduced by a changed lifestyle and greater awareness of health issues (Löllgen and Löllgen 2009, pp. 553-554). Thus, medical findings may turn out to be important to life insurance price determination in the future.

\footnotetext{
${ }^{3}$ American research intensively dealt with fairness issues and the adjustment of insurers' pricing methods because of gender discrimination during the late seventies. The starting point of this process in the U.S. were debates on the adequacy of using group mortality tables in pricing pension plans that result in different pension payments for both sexes. Several authors analyze whether the use of these gender-specific tables is fair and examine how they may lead to gender discrimination in pension scheme calculation (Hedges 1977; Martin 1977; Myers 1977; Brilmayer et al. 1979; Kimball 1979; Laycock and Sullivan 1981; Benston 1982, 1983; Hickman 1983). Two U.S. Supreme Court judgments (the Manhart Case, U.S. Supreme Court 1978 and the Norris Case, U.S. Supreme Court 1983) ruled that the use of life tables that lead to differences in pension payments for each sex violates Title VII of the 1964 Civil Rights Act.

${ }^{4}$ The use of genetic tests in pricing life insurance is banned within most Western Europe states, with a few exceptions for high sum insurance (Durnin et al. 2012, p. 127). This aspect is not further explored in this study because the use of genetic tests continues to have little relevance for insurance pricing.
} 
Also approaches are analyzed in literature taken by nonlife insurance, in particular motor insurance, for the development of risk-based pricing. In particular, the issue of usage-based technologies has been at the forefront of public and scientific discussions (Wenzel 1995; Edlin 1999; Khazzoom 2000; Ippisch and Thiesse 2007; Litman 2011a; Bolderdijk and Steg 2011; Lemaire et al. 2012). Litman (2011b) provides a detailed overview of various methods and considers the advantages and disadvantages of each model. Wenzel finds that the implementation of usage-based technologies in current pricing models enables an insurer to price "more on a driver's relative exposure to a potential accident" (Wenzel 1995, p. 1). However, until now, this mechanism incurred high costs as well as raised data protection concerns and therefore, did not enjoy widespread use. ${ }^{5}$ New technologies as well as advances in data collection and storage could enable insurers to reduce implementation costs and communicate premiums in a transparent manner (Ippisch and Thiesse 2007; Simon Kucher \& Partners 2011b).

In the field of marketing science, customer-oriented pricing in reference to consumers' perception regarding pricing and the company relevance is often only discussed in terms of goods and services. Consumers assess a product's value and quality based on its price (Schechter 1984; Dodds and Monroe 1985; Burton and Lichtenstein 1990; Bolton and Drew 1991). Shipley and Jobber (2001, p. 304) argue that price influences consumers' selection of a preferred brand and therefore, understanding consumers' needs "is key to effective pricing." Zeithaml analyzes the challenges service providers face to evaluate customers' needs and develop products accordingly (Zeithaml 1981, 1988). Matzler et al. (2006) investigate various dimensions of price satisfaction and find that price transparency, price fairness, price reliability, and price confidence (among others) have a lasting effect on consumers' satisfaction (Matzler et al. 2006, p. 216). As per the research of Homburg et al. (2005), satisfied consumers are willing to pay higher prices.

However, customer-oriented pricing is fetching an increasingly important avenue for the insurance industry to achieve profits in today's competitive market environment. Furthermore, customer behavior is changing, which also impacts insurer's pricing strategies (Catellani et al. 2004; Bieck et al. 2008; Bain \& Company 2012; Ernst \& Young Global Limited 2012; Capgemini and Efma 2013). New technologies can support insurer's ability to meet the challenges of pricing process refinement (IBM Global Business Services 2006; Bieck et al. 2008; Scherer and Schmeiser 2010; Insurance Europe 2013a).

This study creates a novel contribution to the literature. In considering the status quo, the question arises concerning how insurers' pricing models can be developed to benefit both the customer and the insurer. Therefore, we combine two literature traditions, namely, that on risk classification based on cost-oriented pricing and that on customer-oriented pricing based on consumers' willingness to pay. We analyze how consumers' perceptions can impact the risk-adequate pricing process based on price- determining factors. In addition, we address the question of whether consum-

\footnotetext{
${ }^{5}$ The pay-as-you-drive (PAYD) approach has been partially tested through pilot projects and was successfully implemented in pricing motor insurance by several countries, e.g., the U.K. and the Netherlands. Insurers in Germany and France have also considered introducing PAYD insurance rates.
} 
ers are willing to go beyond current pricing practices. This question is relevant to insurers because the more precisely an actuarial unit's cost can be determined, the more efficient and profitable pricing will be. From the consumers viewpoint, in contrast, targeted use of personal information for pricing serves to increase transparency and ease of comprehension.

\section{Insurers' pricing practices for motor and term life insurance in Europe}

This section provides comparative overviews of the three largest European insurance markets as well as risk classification practices for motor and term life insurance. These overviews are designed to provide the understanding of national insurance markets' structures as well as classification practices across different product lines. These considerations provide a basis for the questionnaire presented in Sect. 3.1 and the discussion of the survey results in Sect. 3.2.

\subsection{Overview of the European insurance market}

In terms of world market share, the European insurance industry ${ }^{6}$ remains the world's largest industry (33.3\% in 2012), ahead of North America (30.2\%) and Asia (29.2\%) with a total premium volume of US\$ 1535 billion (Seiler et al. 2013, p. 33). Life insurance premiums currently comprise $33.4 \%$ of global premiums (US\$ 876 billion), while nonlife insurance premiums comprise $33.1 \%$ of global premiums written (US\$ 659 billion, Seiler et al. 2013, p. 33). The insurance industry’s market penetration (premiums in \% of GDP) amounts to $6.73 \%$, while insurance density (premiums per capita) amounts to US\$ 1724.4 (Seiler et al. 2013, p. 33 and p. 40). Measured by total gross premiums, the U.K (US\$ 336 billion), France (US\$ 288 billion), and Germany (US\$ 256 billion) are the largest and most important insurance markets in Europe (The data relate to the year 2012, Organisation for Economic Co-operation and Development 2012). All three countries recorded a decrease in premiums in 2012, in life insurance, and the U.K. also recorded a decrease in nonlife insurance premiums (Seiler et al. 2013, pp. 38-39).

Premiums written vary not only from country to country but also between product lines. In addition, regional markets differ in terms of structure, while various product lines differ regarding the risk factors used in pricing. In the following section, we first provide a detailed overview of these differences with a focus on environmental determinants behind the development of various distribution structures across the three main European insurance markets. Second, we consider the theory of pricing practices with a focus on risk classification in motor and term life insurance.

Insurance industry in the United Kingdom. In terms of total premium income, the U.K.'s insurance industry is the third largest in the world after the U.S. and Japan as

\footnotetext{
${ }^{6}$ The European segment includes Western (31.7\% of global premiums written) as well as Central and Eastern Europe $(1.6 \%)$. The latter countries together comprise one percent of global premiums written (Seiler et al. 2013, p. 33).
} 
well as the largest in Europe with a market share of $6.8 \%$ (Seiler et al. 2013, p. 35). "The U.K. insurance industry generates $22 \%$ of total EU premium income" (Association of British Insurers (ABI) 2013, p. 2). Life insurance is the industry's largest product line, comprising $70 \%$ of total premium income in 2011 (Insurance Europe 2013 b, p. 3). The nonlife insurance sector's market penetration amounted $11.3 \%$ in 2012 (life insurance 8.4\%), and insurance density reached US\$ 4350 (Seiler et al. 2013, pp. 40-40). The sector's current workforce of 320,000 employees illustrates its economic importance to the U.K. (ABI 2013, p. 3).

The insurance industry has a long history in the U.K. Low market entry barriers and an active private sector played a key role in the industry's development. The insurance market is strongly self-regulated, i.e., self-regulating organizations ensure consumer protection and prevent increased state level regulation (Wolf 2009, p. 44). The market's structure is moderately fragmented and the industry encompasses smaller insurance companies as well as globally oriented firms (MarketLine 2012c, p. 17). Insurers' business models and product ranges are often similar, with the consequences that consumers exhibit high levels of price sensitivity and insurers' experience low profit margins (MarketLine 2012c, p. 17). Thus, a highly competitive market environment exists.

Overall, buyer power is moderate and insurance substitutes are low (MarketLine 2012c, p. 12). Low consumer loyalty can be attributed to high willingness to compare premiums and benefits before selecting a provider. This willingness has contributed to the successful establishment of several insurance product comparison websites (MarketLine 2012c, p. 13). In sum, U.K. customers are independent, have a high tendency to switch insurers, and are rather financially strong and have very price sensitive traits that (among others) are reflected in their use of different distribution channels.

Brokers are the most widely used distribution channel for nonlife insurance, with a $37 \%$ market share, followed by direct writing (35\%), bancassurance (12\%), affinity groups (11\%), company agents (4\%), and other channels (1\%, ABI 2013, p. 14). Distribution channel use has changed the most in the highly competitive motor insurance product line because of new technologies (e.g., the Internet) as well as increased collaborations with car dealers (CEA Insurers of Europe 2010, p. 10). For life insurance, consumers prefer personal advice: $76 \%$ of policies are purchased from independent financial advisors offering whole of market advice, 17\% from non-intermediaries, and $7 \%$ by single tied advisors (ABI 2013, p. 14).

Insurance industry in France. With a market share of $5.3 \%$, the French insurance industry is the fifth largest in the world (after the U.S., Japan, the U.K., and China) and the second largest in Europe (Seiler et al. 2013, p. 35). Analogous to the U.K., life insurance is the French industry's largest product line, comprising $66 \%$ of total insurance premium income in 2011 (Insurance Europe 2013b, p. 3). Total premium to GDP ratio amounted to $8.9 \%$ and premiums per capita totaled US\$ 3543 in 2012 (Seiler et al. 2013, pp. 40-41).

The French market has a compact structure. Large companies (i.e., AXA, BNP Paribas Group, CNP Assurances SA and Crédit Agricole Group) dominate the insurance market with only a few small providers offering alternatives (MarketLine 
2012a, p. 13). Financial institutions and banks that expanded into the insurance market serve as an important sales channel (MarketLine 2012a, p. 16). Regulation is strict, though not as strong as in other financial sectors (MarketLine 2012a, p. 15). As in the U.K., new technologies have increased French customers' market power. Aggregators and the possibility of obtaining online information regarding prices and services have led to increased transparency (MarketLine 2012a, p. 13). Therefore, policyholders exhibit increased price sensitivity and decreased loyalty to a particular provider (MarketLine 2012a, p. 13).

The French insurance market uses several types of distribution channels, e.g., tied agents, insurance brokers, salaried sales forces, and direct writing mutuals as well as banks and financial institutions (CEA Insurers of Europe 2010, p. 23). However, recently, the highly competitive market environment and influence of new technologies have led to a consolidation of channels. Direct marketing and alternative distribution channels, e.g., car dealers and manufacturers, are gaining influence (CEA Insurers of Europe 2010, p. 23). The consumers preferred channel varies with product line. The nonlife market is dominated by tied agents and direct writing offices, which together account for approximately $35 \%$ of market share, followed by brokers (CEA Insurers of Europe 2010, p. 24). In life insurance, policies are mainly sold by financial institutions and banks (64\%), followed by direct writing (15\%), brokers (12\%), and agents, who account for 7\% (CEA Insurers of Europe 2010, pp. 23-24). In the nonlife sector, the concept of bancassurance performs well in motor insurance. In this product line, insurance and banking are closely linked (7\% market share, CEA Insurers of Europe 2010, p. 10).

Insurance industry in Germany. Measured by global premium volume, the German insurance industry is the sixth largest in the world (market share works out $5 \%$, Seiler et al. 2013, p. 41). Total premium income distribution between life (49\%) and nonlife insurance (51\%) was nearly equal in 2011 (Insurance Europe 2013b, p. 3). Its penetration amounted to $6.7 \%$ and insurance density reached US\$2804 in 2012 (Seiler et al. 2013, pp. 40-41).

The market structure is moderately fragmented, as in addition to the large companies (i.e., Allianz Group, AXA, ERGO Versicherungsgruppe AG, and Generali Deutschland Holding AG), a multitude of small insurers exist, unlike in France (MarketLine 2012b, pp. 2-3). Competition within the industry is (partly) high because of the lack of diversity and undifferentiated products as well as a high number of similar market players (MarketLine 2012b, p. 17). In the past decade, the buyers' market power has risen because of new technologies' impact on the demand process, especially in the nonlife insurance sector. Consequently, consumers have become increasingly independent and price sensitive with low loyalty (MarketLine 2012b, p. 13). This is especially noticeable in motor insurance where price competition is fierce and growth rates are low. In life insurance, however, buyers' power is rather low because of higher switching costs (MarketLine 2012b, p. 15).

The classical German distribution channel is the exclusive sales organization (CEA Insurers of Europe 2010, p. 25). However, distribution channels have expanded because of deregulation and technological developments (Jannott 2001, p. 598). Although, cost-oriented online insurers recorded rising growth rates, agents still sell 
over $60 \%$ of nonlife insurance policies (CEA Insurers of Europe 2010, p. 25). Motor insurance market shares can be broken down as follows: agents $(61 \%)$, brokers (17\%), company employees (10.2\%), other intermediaries ( $7 \%)$, and bancassurance (4.8\%, CEA Insurers of Europe 2010, p. 25). In life insurance, most insurance policies are offered by agents $(46.5 \%)$, followed by brokers $(21 \%)$ and bancassurance (20.3\%), company employees (9.8\%), and other intermediaries (2.4\%, CEA Insurers of Europe 2010, p. 25). The bancassurance channel is much less important than in France, and the broker channel is much less important than in the U.K.

The European insurance industry developed different market structures because of various economical, political, and legal as well as cultural conditions. For strategic price management, different national consumer patterns should be incorporated into planned customer communication and product distribution. The abovementioned circumstances have, for example, formed different distribution channels that consider individual consumers' information and purchasing behavior in each country and for each product line.

\subsection{Theory of insurers' pricing principles}

The marketing aspects of pricing insurance were largely ignored in the past as companies focused on cost-covering underwriting and satisfactory profits (Murdock and McGrail 1994, p. 1). In addition, insurance companies balked at revealing too much insight into their pricing processes, not least because of concern over increasing regulatory intervention and the possible competitor reproduction of premium models (Murdock and McGrail 1994, p. 1). The high (75\%) proportion of cost-oriented pricing is attributable to some of these aspects (Gard and Eyal 2012, p. 3).

The standard approach of determining premiums follows the actuarial pricing model - a practice which is not expected to change for the predictable future (Gard and Eyal 2012, p. 3). The core insurance business is risk coverage, i.e., a policyholder transfers "the financial consequences of an existing risk for a known [...] amount (premium)" to the insurer, which granted him to take over it in the event of a claim (Teufel et al. 2001, p. 4). Therefore, to remain solvent, insurers must balance two different responsibilities: (1) the "need to earn sufficient income from premiums to cover anticipated claims" (Oxera Consulting 2012, p. 5) in proportion to their relative hazard of loss and (2) the need to ensure policyholders' economic situations by making appropriate payouts (De Wit 1986, p. 645). To maintain this complex and constantly changing balance, detailed knowledge is required concerning possible individual loss occurrence, the probability of potential damage, and expected claims amount. Thus, risk selection and differentiation are fundamental components of insurers' underwriting and pricing processes. The aim of risk-adequate pricing is to determine costs for one actuarial unit as precisely as possible by using risk-determining factors.

Cost-oriented pricing and customer-oriented pricing requires calculating costs as accurately as possible. In the first case, premiums are calculated based on the claim's expectation value and extra costs for safety loading and operating costs surcharge as well as installment, insurance tax, and profit margin (Belth 1967, p. 386). Furthermore, precise data on relevant costs are essential to identify the profit-maximizing 
combination of price and quantity needed to utilize the consumers' willingness to pay (Farny 2011, p. 45).

The law of large numbers is highly relevant to insurers' underwriting at a costcovering level. The more comparable and preferable uncorrelated risks existing in an insurance portfolio, the more predictable the expected claims experience will be (Teufel et al. 2001, p. 4). Risk characteristics are used to map and evaluate the probability distribution of damage. Therefore, risk-rating factors have to be "based on sound actuarial principles and related to actual or reasonably anticipated experience" (Actuarial Standards Board 2005, p. 9). Based on these criteria, the insurer defines several risk groups with similar probabilities of loss occurrence and expected claim amounts. Each group's premium depends on its expected loss (Abraham 1985, p. 407).

For insurance companies, accurate underwriting is the foundation of a solvent business (Teufel et al. 2001, p. 20). Therefore, insurers seek to determine an individual customer's expected loss probability as precisely as possible before offering insurance coverage (Rothschild and Stiglitz 1976, p. 632). ${ }^{7}$ Degree and extent of risk classification depends upon, among other factors, both the size of the insurer's portfolio and cost aspects. Risk-based pricing is cost-intensive (Walters 1981, p. 1). Consumers' data have to be collected over a long period before they can be used as a statistically proven risk-rating factor (ABI and Oxera 2010, p. 13). Therefore, highly differentiated risk classification is not economically desirable or even costeffective for every insurance company (Crocker and Snow 1986; Borenstein 1989). In addition, risk classification and the avoidance of adverse selection will not yield advantage to every customer. Currently used risk factors represent customers' "levels of safety or levels of activity" (Abraham 1985, p. 414). Therefore, risk-averse individuals usually pay lower premiums for insurance coverage. By contrast, high-risk individuals pay more for their insurance policies and thus, benefit from less accurate risk selection and subsequent inadequate premiums (Teufel et al. 2001, p. 12).

Current risk classification procedures face some significant challenges. Besides a competitive market environment, various risk-rating factors "commonly used are being questioned by regulators" (Lemaire et al. 2012, p. 22). Therefore, insurers must find risk-rating factors that can be determined as accurately as possible and also earn social acceptance (Lemaire et al. 2012, p. 22). These aspects together with legislated increasing transparency requirements mean that the intensified application of customer-oriented pricing can create a competitive advantage (Murdock and McGrail 1994, p. 1).

\footnotetext{
${ }^{7}$ From an economic viewpoint, risk-adequate pricing based on various risk-rating factors help to reduce information asymmetries (Teufel et al. 2001, p. 17). This phenomenon is widespread in the insurance market, with the consequence that insurers often only know a potential policyholder's average loss occurrence probability (Teufel et al. 2001, p. 17). Without risk differentiation based on individual consumer data, insurance companies determine price based on the worst risk. The result is that "good" risks are too expensive and the premiums for "bad" risks are accordingly too low (Abraham 1985, p. 408). These adverse selection effects can lead to financial losses, and under unfavorable management or market conditions, they can also result in market failure with negative effects for society as a whole (Akerlof 1970, p. 488). Furthermore, inadequate risk evaluation and classification lead to unfavorable risk behavior (namely, moral hazard, Abraham 1985, p. 405). Rothschild and Stiglitz (1976, p. 648) argue, "if individuals were willing or able to reveal their information, everybody could be made better off."
} 
Until now, cost-oriented pricing stood at the forefront of underwriting. If insurers know which risk factors out of the high volume of collected data will be accepted by customers, they can give these increased prominence when determining premiums. However, less accepted risk characteristics that have low impact on the premium amount should be accorded reduced prominence or dropped from price calculations. Furthermore, greater customer involvement in the pricing process may increase their understanding of pricing practices and insurers' need for data. These in turn could lead to better data quality. Consequently, insurance premiums can be calculated more precisely and customers equity can be defined more exactly (Erdönmez et al. 2006, p. 39). The more precisely a risk can be identified and valuated, the better insurance companies can avoid miscalculations (Werner 2013, p. 65). Thus, customer-oriented pricing based on technical risk-based underwriting represents a significant competitive advantage in a competitive market. On the one hand, refined cost-covering pricing is possible, and on the other hand, such a practice renders it much more difficult to reproduce competitors' premium structures. Usage-based premiums may support this development in future (Erdönmez et al. 2006, p. 51).

Pricing of motor insurance. The motor insurance industry incorporates the majority of risk factors in underwriting. This reflects the fact that vehicle-specific attributes as well as individual customer characteristics are taken into consideration in premium calculation. However, while insurance companies gather an average of 21 risk characteristics on consumers, they only apply 12 different risk-rating factors in their pricing practices (Erdönmez et al. 2006, p. 38). Analyses of European insurers' pricing models illustrate the influence of various risk characteristics on insurance premiums (Erdönmez et al. 2006; Störmer and Wagner 2013). In terms of personspecific attributes, age has the highest significant influence on premium calculation (Erdönmez et al. 2006, p. 40). With regard to vehicle-specific attributes, type of car has a highly significant influence upon risk premium. Higher value vehicles incur higher surcharges (Hoy 1982, p. 321 and Störmer and Wagner 2013, p. 13). Annual mileage is another important risk factor used in underwriting as a great number of kilometers traveled per year means higher crash costs (Litman 2011a, p. 1) and "the number of claims at fault" (Lemaire et al. 2012, p. 22). Other factors having influence include purpose and number of drivers as well as the vehicle's initial registration date (ABI and Oxera 2010, p. 19). Furthermore, environmental factors are used in the underwriting process. In urban areas, higher traffic means a higher likelihood of accidents compared to less populated areas (Etgar 1975, p. 617). This aspect is determined by the policyholder's place of residence. Although many insurers collect data regarding the presence of a garage, for most companies, the garage criterion has no significant impact on final premium (Störmer and Wagner 2013, p. 17). Table 1 shows typical risk-rating factors used in motor insurance. Vickrey (1968) argues that the current methods are based on reliable and up-to-date consumers' information. He was one of the first authors to consider ways to adapt risk classifications used in premium calculation in relation to kilometers traveled per year (Vickrey 1968, p. 472). Technological progress gradually led these usage-based methods to be gradually applied throughout Europe (mainly in form of PAYD). Insurers can contribute to risk avoidance through implementing this approach as PAYD enables insurers 
Table 1 Overview of main risk-rating factors used in motor and term life insurance

\begin{tabular}{ll}
\hline Motor & Age, vehicle make, annual kilometers, purpose of vehicle, occupation, place of resi- \\
dence, homeowner, initial vehicle registration, garage, engine output, marital status, \\
type of vehicle financing, drivers, owner of a railcard, vehicle replacement value, use of \\
a black box, integrated tracking device
\end{tabular}

The risk factor use of a black box is only applied in pricing motor insurance in the U.K. The attribute integrated tracking device is used by insurance companies in the U.K. and France

to ensure insurance premiums to reflect individual risk behavior. "Safe behaviors should be rewarded and risky behaviors penalized" (Bolderdijk and Steg 2011, p. 5). Moreover, use of this technology leads "to increasing actuarial accuracy" (Litman 2011a, p. 1). Lemaire et al. (2012) argue that an "accurate rating system should include annual mileage [tracked with PAYD technologies] and bonus-malus as the two main building blocks, possibly supplemented by the use of other variables such as age and territory."

Pricing of term life insurance. Term life insurance pricing requires as accurate as possible calculation of the policyholder's probability of dying over a specific timeframe (ABI and Oxera 2010, p. 27). Therefore, policyholder age has the highest impact in risk-based pricing (Störmer and Wagner 2013, p. 14) because of its correlation with mortality rate (De Wit 1986, p. 645). Furthermore, information regarding customer health status and body mass index (BMI) are often used for pricing term life insurance. In this context, medical examinations are sometimes essential prior to the conclusion of a contract. Personal behavior factors are taken into consideration, such as alcohol consumption, medications required, and hobby participation (Löllgen and Löllgen 2009, p. 554). The attribute of smoker or nonsmoker has a high influence on insurance premium, reflecting smokers' increased risk of death from lung cancer (Fillenbaum et al. 2007, p. 66). In addition, policyholder's place of residence is used to map socio-economic status (ABI and Oxera 2010, p. 27). Furthermore, urban areas have lower environmental quality, therefore, access to healthcare is often more expensive (De Wit 1986, p. 654). The risk factor of occupation accounts for the risk class of the policyholder's profession (De Wit 1986, p. 654). Table 1 presents an overview of main risk-rating factors used in term life insurance.

Breakthrough medical discoveries may affect the insurers' risk classification systems in future, e.g., the link between healthy lifestyle behavior and decreasing mortality (Behrens et al. 2013, p. 361). Therefore, several low-risk lifestyle attributes (such as regular exercises, balanced diet, and long-term nonsmoker) have a positive impact on the probability of dying in a specific timeframe (Behrens et al. 2013, p. 361). Thus, a healthy lifestyle and health conscious behavior (e.g., relaxation, regular health checks, and quality sleep) promote health and decrease mortality risk (Löllgen and Löllgen 2009, p. 554).

Technological developments offer insurance companies the possibility of optimizing their risk-based pricing. Vehicle-related technologies offer the possibility for precise data collection. Communication and information technologies, in turn, enable simplified data collection and a systematic evaluation of the gathered information 
(IBM Global Business Services 2006, p. 6 and Ernst \& Young Global Limited 2012, p. 27). Purposeful evaluation and the use of customer data would allow insurers to evade as far as possible pure price competition. In addition, technologies can support insurers' development of price and communication strategies that can be tailored to customers' needs (Ernst \& Young Global Limited 2012, p. 27). Such a process, however, requires knowing how consumers understand and evaluate current pricing practices. Therefore, analyzing the difference between the use of price-determining risk factors and consumers' acceptance of these factors will enable insurance firms to further refine and tailor their pricing policies to best balance consumer price expectations with the firm's continued financial solvency.

\section{Consumers' acceptance and readiness to make personal risk factors available for insurers' pricing}

Only $10 \%$ of insurance firms practice customer-oriented pricing (Gard and Eyal 2012 , p. 3). Customer-oriented pricing means "the whole process of added value for customers and disgorgement of value for insurers. This is based on the comprehensive knowledge of individual customer's needs and to design from this knowledge products for the respective target group" (Schmidt-Gallas and Beeck 2007, p. 11). Integrating customers' views of pricing and their price sensitivity in the initial method of "cost-oriented pricing [...] based on claims experience" (Gard and Eyal 2012, p. 2) can help a firm achieve competitive advantage.

Furthermore, the issue of transparency plays an important role in demand for insurance. $77 \%$ of consumers favor "transparent and clear documentation" in insurance quotes (Bieck et al. 2008, p. 5). Thus, transparency ranks most important for price sensitive consumers (Bieck et al. 2008, p. 6). Public debate is already addressing the need to improve transparency. At EU level, transparency and a uniform Europe-wide approach to this topic are the main drivers of financial industry regulation (Bieck et al. 2008, p. 10).

A cross-national (i.e., the U.K., Germany, France, Italy, and Switzerland) consumer survey conducted in 2011 shows that commonly used price-determining factors in insurance pricing enjoy wide acceptance by the majority of the population (Schmeiser et al. 2014, p. 10). In each of four requested product lines (i.e., motor, annuity, term life and private health insurance), the most relevant price differentiation criteria are taken into account by the authors of the study. The questionnaire was designed such that the respondents explicitly know that all requested attributes are already applied in the insurer's premium calculation.

On this basis, this study examines whether or not consumers accept commonly used risk factors even if not explicitly informed of their use in pricing. Furthermore, we intend to deepen our analysis by examining which individual consumer characteristics support the further development of insurers' pricing process. Based on these findings and the increased relevance of technological developments for improved data collection and analysis, the question arises which additional person-specific attributes customers would make available to insurers for use in premium calculation. 
The purpose of this section is to analyze consumers' acceptance of insurers' using various price-determining risk factors as well as their willingness to provide personal information for insurers' underwriting. The analysis of consumers' acceptance regarding various risk factors focuses on whether or not insurers' pricing process requires adjustment to align with consumers' expectations. Insurers can increase their pricing model's efficiency by incorporating the additional risk-rating factors and personal information that consumers are comfortable sharing. Therefore, we consider which currently used characteristics enjoy general acceptance by consumers and thus, could be granted greater consideration in current premium calculation compared to less accepted attributes. We also investigate which characteristics might play a role in future pricing models to elaborate upon current premium calculation models that incorporate customers' views.

\subsection{Survey description}

In this section, we present the results of a cross-national online consumer survey conducted in July 2013 in the U.K. ( $n=503$ respondents), Germany $(n=500)$, and France $(n=504)$. A total of 1507 consumers were surveyed in their respective language version. The questionnaire was designed to gather information regarding consumers' opinions of insurance pricing and to identify their judgment concerning the acceptability of insurers asking about various individual risk characteristics or incorporating them into pricing in motor and term life insurance. The survey sample is representative for the local population concerning gender and age (18-65 years) for each country. Furthermore, four additional socio-demographic characteristics were collected: (co-)deciders for private households on the subject of insurance, level of education, current job situation, and household income.

Respondents were given two separate lists of 35 risk criteria one tailored for each insurance line. The lists provided both currently used as well as unused risk factors in insurance pricing (as per the criteria described in Sect. 2.2). The currently used risk factors comprise the most relevant price differentiation criteria. That is, for motor insurance, the characteristics of a vehicle selected are: car make, kilometers driven per year, garage or street kept, initial registration date, type of financing, purpose, number of drivers, engine output, replacement value, use of a black box, and presence integrated tracking device. Policyholder attributes considered are: age, homeowner status, marital status, place of residence, owner of a railcard, and occupation. For term life insurance, currently used attributes included in the survey are: customer age, smoker status, body size, BMI, highest educational attainment, occupation, hobbies, illnesses/disabilities, alcohol consumption, and medication use. Currently unused characteristics include, for example, attributes of one's personal lifestyle or behavior. Furthermore, the unused attributes comprise a group of factors requested for use as control group to identify logical response patterns. This group includes, for example, the customer's shoe size or if he or she is a dog owner. To allow comparison between product lines, 27 criteria were used in both motor and term life insurance attribute lists. Moreover, this approach allows conclusions to be drawn regarding consistent responsiveness. All risk factors included in the questionnaires are provided in the Appendix. The respondents were provided with a simple list of attributes and 
indicated their acceptance of each using a five-level Likert scale ranging from " $0=\mathrm{I}$ feel this is not acceptable" to " $5=\mathrm{I}$ feel this is entirely acceptable." The questionnaire can be found in the Appendix.

\subsection{Data analysis and survey results}

The survey reveals that consumers' acceptance of various risk-rating factors and their willingness to provide information to insurers differs across both the three countries surveyed and the two product lines requested. Table 2 shows the descriptive statistics of our survey results. These results depict the average consumers' approval ratings for each risk characteristic in each country and product line as well as the average standard deviation. The letters (A, a) indicate significant differences between mean values in the three countries surveyed.

\subsubsection{Currently used risk factors in insurance pricing}

The 35 attributes investigated cover attributes already used in pricing motor and term life insurance. We included 15 factors currently employed in pricing motor insurance common to all three countries. The factor use of a black box is only applied in U.K. insurer's pricing models. The attribute integrated tracking device is used by British and French insurance companies. Ten attributes currently used in term life insurance pricing models were included. All currently used attributes are marked by an asterisk (* used in motor insurance, $* *$ used in term life insurance, and *** used in both product lines) in Table 2.

When analyzing consumers' acceptance level of these surveyed risk factors, we discover that consumers accept the majority of currently used price determining factors in comparison to attributes not yet used. In addition, differences exist between the three countries and across both product lines.

Country comparison. U.K. respondents exhibit the highest acceptance of insurers asking about commonly used characteristics for inclusion in pricing both motor (11 out of 17 currently used attributes) and term life insurance (7 out of 10 attributes). Furthermore, U.K. respondents also express the highest average willingness to provide insurers with personal information above the average with a mean of 3.48 in motor and 3.40 in term life insurance. Moreover, U.K. respondents give 6 motor insurance attributes a rating of 4 . Neither of the surveyed groups in France and Germany gives such high ratings. The French respondents have higher acceptance and readiness to provide information to insurers (mean of 3.18) than German respondents (2.92) in motor insurance. In term life insurance, the opposite pattern emerges. Respondents in both these countries reject mainly the same currently used criteria.

Comparison of insurance lines. When analyzing the results from product lines, the overall acceptance level of currently used risk factors is higher in motor insurance (3.18) than in term life insurance (2.98). The criteria kilometers and engine output in motor insurance receive the highest acceptance and willingness to provide such information to insurers, with a mean of 3.90 . 


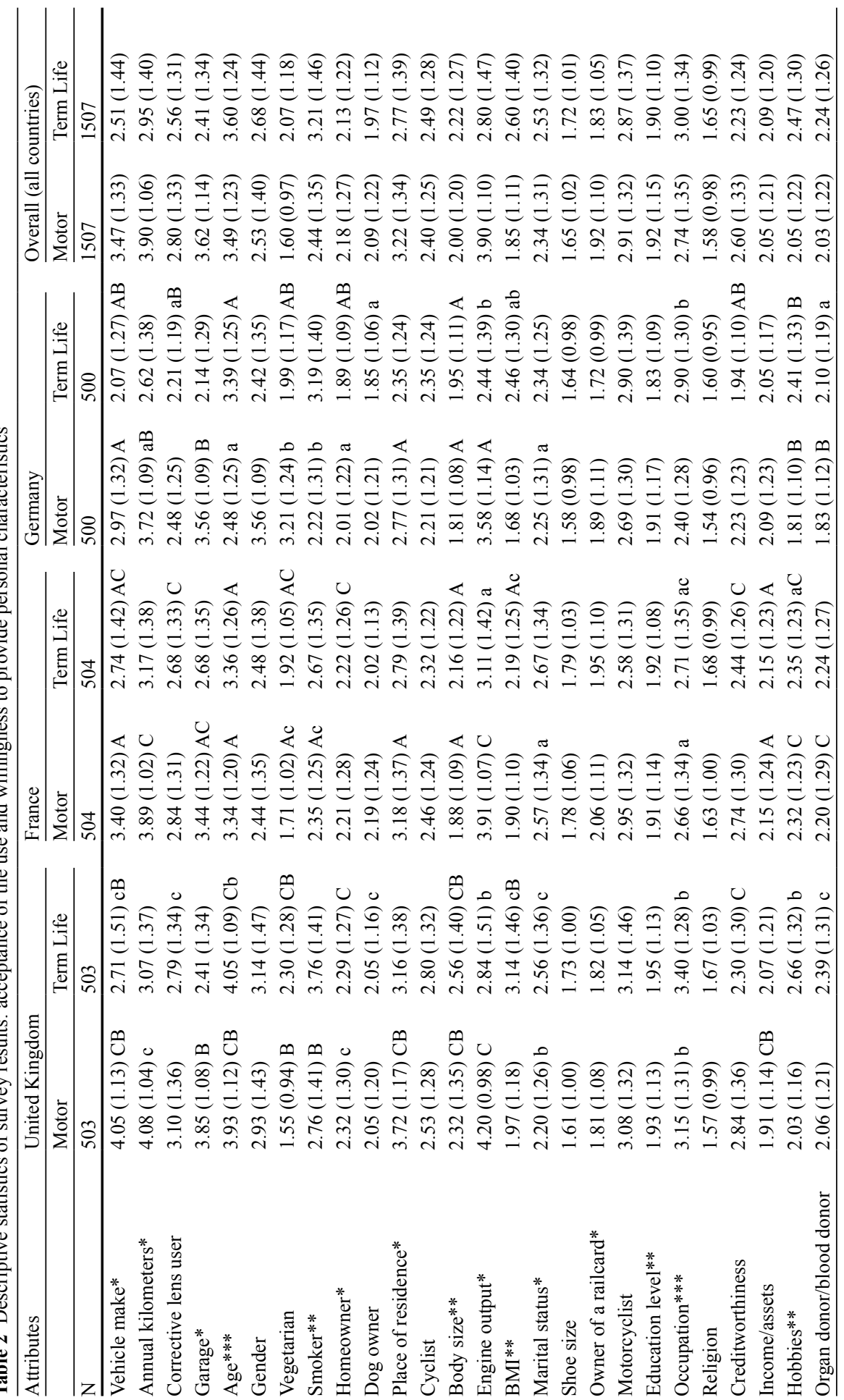




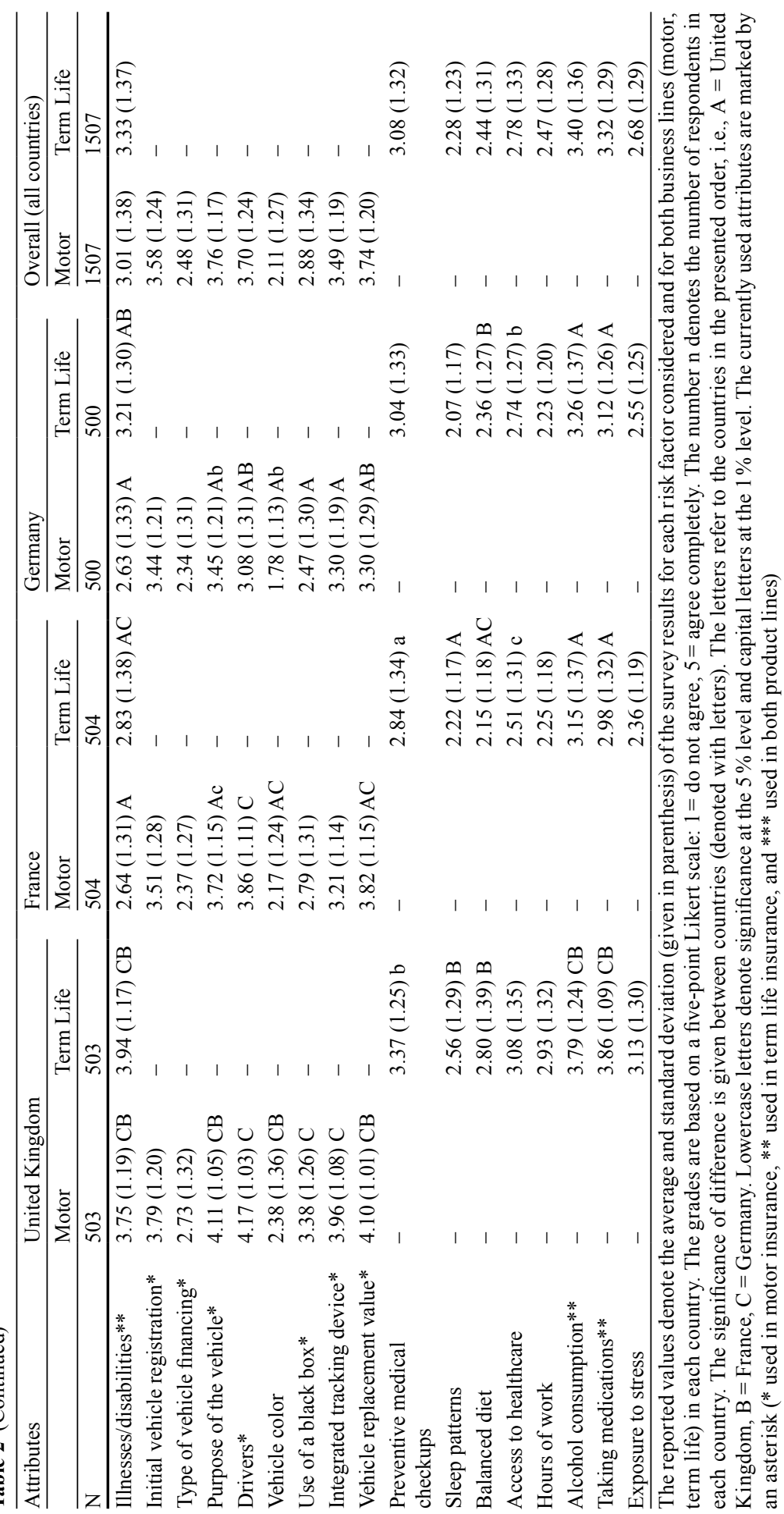


In general, most consumers express higher support for vehicle-specific criteria rather than person-specific characteristics. The latter are partially rejected, e.g., owner of a railcard (1.92), homeowner (2.18) and marital status (2.34). By contrast, age as a personal factor outside of respondent's control receives high reception in both product lines. In fact, in term life insurance, age is the most supported risk-rating criterion, with a mean of 3.60 .

\subsubsection{Currently unused risk factors}

The criteria surveyed comprise three groups. In addition to commonly used risk factors (group one), we also included attributes that have been discussed in the scientific literature as well as in public debates (Sect. 2.2), e.g., use of PAYD technology in motor insurance and healthy lifestyle attributes in term life insurance (group two). We also included notional attributes for use as control variables to verify whether differentiated response behavior was displayed (group three). For this purpose, among others, motor insurance risk-rating factors were queried analogically in the term life insurance list.

Cross-country comparison. In analyzing the survey results, consumers in all countries clearly reject attributes not yet used in insurers' pricing practices with a few exceptions. Excluding the notional attributes, the average approval rates for currently unused criteria are lower than the scale's neutral point (a rating of 3 corresponds on our five-level Likert scale to the neutral position). As in the case of currently used risk factors, U.K. respondents have the highest average approval rate for currently unused risk factors in both product lines, followed from respondents from France and Germany.

Comparison of insurance lines. Our analysis of the attributes requested by both insurance lines reveals differences in consumers' willingness to provide support for the insurers' use of personal information. Consumer approval of collection and use of personal information is higher on average in term life insurance than in motor insurance. Notably, despite the fact that consumers are willing to provide health status information to insurers and engage in behavior such as having preventive medical checkups, which indicate a high willingness to share personal information with insurers, some attributes currently not used in insurers' pricing garner higher approval rates than some currently used characteristics. In term life insurance, for example, access to healthcare and exposure to stress ranked higher than currently used risk factors BMI and policyholder's hobbies. Furthermore, some vehicle-specific characteristics and criteria regarding traffic achieve a higher rating on the scale for term life insurance compared to person-specific attributes, e.g., engine output and kilometers traveled per year as well as motorcyclist in comparison to hobbies, sleep patterns, and highest educational certificate attained. Regarding the first three characteristics, U.K. respondents would provide personal information concerning kilometers traveled per year and motorcyclist. In term life insurance, French respondents are willing to inform insurers regarding their engine's output and also kilometers traveled per year. In motor insurance, the criterion integrated tracking device (3.49) has fairly 
widespread acceptance; this level is calculated excluding respondents from the U.K., where this criterion (3.96) as well as use of black box (3.38) are established risk-rating factors, which enjoy high consumer acceptance. German and French respondents demonstrate higher approval for the use of a black box to record individual driving behavior (2.88) as a price-determining risk attribute compared to some already used risk factors in pricing motor insurance, e.g., owner of a railcard (1.92), homeowner (2.18), type of vehicle financing (2.48) and policyholder's occupation (2.74). Furthermore, health aspects that may affect policyholder's driving ability are assessed as relevant for pricing motor insurance, e.g., illnesses/disabilities with a mean of 3.01 and corrective lens user (2.80, compared to owner of a railcard with 1.92 or homeowner with 2.18).

Finally, socio-demographic factors are negligible in consumers' acceptance rates for both currently used and currently unused risk factors. In fact, male respondents show a higher level of acceptance than female respondents. Furthermore, younger respondents are both more satisfied with currently used risk-rating factors and more willing to provide insurers with further information compared to older respondents. However, the differences in response behavior are considerably higher between nationalities than because of other socio-demographic factors.

\subsection{Summary of survey results}

The results of our analysis show that consumers mainly accept price-determining risk factors whose usage they can understand. This comprehension, in turn, requires customers to be able to place the risk-rating factors in context within the premium calculation process of the respective product line. The average approval rate of commonly applied risk characteristics is (in all three countries surveyed and both product lines) higher compared to attributes which have (at present) no effect on premiums. This can be observed particularly in the response behavior of U.K. respondents, who express the approval of the most and highest use of typical risk factors in motor insurance, i.e., engine output, drivers, vehicle make and kilometers traveled per year. A similar picture emerge in term life insurance, where respondents across all countries prefer the use of established risk-rating factors, e.g., policyholder's age, health status, and smoker criteria.

The research confirms previous findings in Schmeiser et al. (2014) regarding consumers' acceptance of currently used risk factors in the insurance industry. The results of the consumer survey conducted in 2011 show that customers support the use of premium differentiation criteria in insurers' pricing practices in almost all product lines surveyed (Schmeiser et al. 2014, p. 10). In addition, in the current analysis, consumers mostly accept the risk-rating factors applied in pricing motor insurance. Moreover, respondents from the U.K. have the highest approval rates compared with the French and German consumers surveyed. The same pattern applies to term life insurance, where consumers generally accept the already used price-determining factors. However, this is not the case for the criterion hobbies, whose use in premium calculation is rejected by the current survey's respondents. In addition, consumers are no longer willing to provide gender-specific information for insurers' premium 
Table 3 Consumers' acceptance of the main risk-rating factors used in motor and term life insurance

\begin{tabular}{lll}
\hline & Motor insurance & Term life insurance \\
\hline Accepted by consumers & Annual kilometers & Age \\
& Engine output & Alcohol consumptions \\
& Purpose of the vehicle & Illnesses/disabilities \\
& Vehicle replacement value & Taking medications \\
& Drivers & Smoker \\
& Garage & Occupation \\
& Initial vehicle registration & \\
& Age & \\
& Integrated tracking device & \\
& Vehicle make & \\
& Place of residence & \\
& Use of a black box & BMI \\
Rejected by consumers & Type of vehicle financing & Hobbies \\
& Marital status & Body size \\
& Homeowner & Education level \\
& Owner of a railcard & \\
\hline
\end{tabular}

The risk factors integrated tracking device and use of a black box are not used in motor insurance pricing models of all three countries surveyed. However, use of integrated tracking device is accepted by consumers of all countries surveyed whereas use of a black box is accepted by British respondents-a country where this risk-rating factor is already used for pricing motor insurance

calculation. Since the ECJ judgment, this feature can no longer serve as a differentiation criteria in insurers' pricing processes.

In contrast with the 2011 survey, the current poll does not indicate which characteristics are used for pricing and which do not affect premiums. However, the respondents almost exclusively support the use of already applied risk-rating factors in both product lines. Table 3 presents an overview of consumers' acceptance of the main risk-rating factors used in motor and term life insurance. Accepted risk factors are defined by a value above the neutral position of 3 on the five-level Likert Scale, and rejected risk attributes by a value below 3 .

Of the total 15 main risk factors in motor insurance, 10 are accepted by consumers for pricing. Vehicle-specific attributes generally enjoy high acceptance, e.g., kilometers traveled per year and engine output. However, consumers mainly reject person-specific risk-rating factors, e.g., owner of a railcard, homeowner, marital status, and occupation. The only vehicle-specific refused characteristic is type of vehicle financing. In term life insurance, consumers accept 6 of 10 price-determining factors. In addition to age, which is a major criterion in pricing term life insurance, consumers especially support the use of factors mapping policyholders' illnesses and health status (e.g., alcohol consumptions, illnesses/disabilities, taking medications, and smoker). Most respondents reject the use of consumer data regarding physique (BMI and body size). Also, policyholders disapprove the use of the risk-rating factor hobbies.

In addition, our research confirms the results that the majority of customers would be willing to provide personal information for further pricing model refinement (Bieck 
et al. 2008, p. 10). Consumers are willing to provide insurers with further information concerning their health status in both product lines, e.g., illnesses/disabilities in motor insurance and having preventive medical checkups in term life insurance. Moreover, consumers support the use of some attributes not currently applied more than the use of already applied differentiation criteria in premium calculation. This is the case for usage-based technologies in motor insurance in comparison to owner of a railcard, homeowner, and type of vehicle financing. Furthermore in term life insurance, consumers express higher approval for attributes that do not yet affect premiums (e.g., access to healthcare, preventive checkups, and exposure to stress than for established differentiation criteria, e.g., policyholder's hobbies and BMI).

\section{Implications for insurers' price management}

In reference to management inquiries, the most effective lever for gaining market share and increasing profits in the coming years is the effective employment of customer-oriented pricing (Erdönmez et al. 2006; Schmidt-Gallas and Beeck 2007; Gard and Eyal 2012). A decisive factor for such effective use is knowing what clients want (Murdock and McGrail 1994, p. 4). Customers often observe today's insurers pricing practices and the current premium calculation as opaque and complicated (Bieck et al. 2008, p. 11). Understanding consumers' needs could help reduce information asymmetries between insurer and consumer as well as "achieve sufficient margin" (Gard and Eyal 2012, p. 4).

Thus, the main goal of this study is to understand customers' perception of the current risk-rating process and estimate to what extent they are ready to help refine the process through the provision of additional personal characteristics. Therefore, we conducted a cross-national consumer survey in the three main European insurance markets. We analyzed consumer acceptance of 35 selected - both already used and notional - price differentiation criteria with descriptive statistics to derive implications regarding how insurers can calibrate their pricing models applying knowledge of consumers preferences regarding risk classification.

Our results produced two main findings. First, by evaluating consumers' perceptions, we are able to show that the majority of consumers accept the use of longestablished risk-rating criteria as their price-determining function can be traced. This is the case for both product lines; consumers prefer risk-rating criteria having a high impact on their premium amount. Second, respondents are willing to provide insurers with further information for pricing. Some attributes not currently used in pricing practices garner higher approval ratings than some currently used characteristics. From these results, it is possible to derive implications for both the refinement and elaboration of the current pricing models and improvement of strategic price communication.

Nowadays, a range of customer information is collected in the insurance purchase process, but some are not applicable in determining the final premium amount (Störmer and Wagner 2013, p. 17). To optimize the pricing process and reduce customers' perceived lack of transparency, data collection should be kept to the necessary minimum. Consumer-specific data should primarily be gathered only if the informa- 
tion is both accepted by consumers and relevant to insurers' pricing. While this study reveal that the main risk-rating factors used for insurance pricing are accepted by consumers, it remains necessary to analyze whether a stronger weighting of these characteristics in determining premiums would lead to higher earning returns (e.g., age in both business lines, vehicle-specific characteristics in motor insurance, and attributes regarding health status in term life insurance). Furthermore, currently used risk factors that are rejected by consumers should be checked to determine if they impact premiums. Criteria that do not significantly influence premiums should not be asked in the purchase process. In term life insurance, the risk factors BMI and hobbies may be examined to determine their application in pricing. If necessary, it could be practical to swap these attributes for more accepted factors not currently used in pricing. For example, consumers are ready to provide health aspects to insurers, i.e., access to healthcare and exposure to stress. In motor insurance, usage-based attributes have higher approval rates than some currently used price-determining factors, e.g., homeowner, type of vehicle financing, and policyholder occupation. Insurers have the opportunity to adjust their pricing practices by applying stronger weighting to clearly explainable and "objectively" perceived risk factors.

In addition, transparency plays a role in consumer's decision to buy insurance policies. Through targeted customer-oriented communication in the context of early explanation of the use of different risk factors, consumers can be made more sensitive to the importance of using such information to derive personally responsive premium rates. Communicating clearly the need for and application of such information reduces the consumer's perceived risk $^{8}$ during the purchase process. The more a consumer can understand process' relevant aspects, the lower its perceived risk (Cunningham et al. 2005, p. 167). Hence, the aspects most often criticized by policyholders, such as high opacity and low reproducibility, can be improved. In this manner, a higher customer acceptance of risk-based pricing can be achieved, and the consumer's decision to buy could be positively influenced (Bieck et al. 2008, p. 11).

In conclusion, companies may be well advised to integrate consumers' perception of risk classification in their pricing process to achieve competitive advantage. High consumer acceptance of commonly used risk factors and high willingness to provide further personal information to insurers may permit the fine adjustment of current pricing methods. At the same time, risk assessment must be effective in costbenefit terms. Risk-based pricing cannot meet all social aspects and consumer needs, but "insurers who can combine sound, [amongst others, through target-customeroriented marketing] and relevant rating variables with the public's view of what is better will obviously be more successful" (Walters 1981, p. 14).

\section{Conclusions}

As previous research presents evidence regarding the importance of adjusting pricing models because of regulatory and economical aspects, this research explores the

\footnotetext{
${ }^{8}$ Cunningham et al. (2005, p. 167) define perceived risk "as a multidimensional construct of physical loss, financial loss, psychological loss, time loss, performance risk, and social risk."
} 
necessity of standardizing insurance pricing schemes considering consumers' perception. To successfully integrate customer elements into pricing strategies, insurers need to know consumers' understanding of price and their acceptance of various price-determining factors.

We surveyed consumers in three European countries (the U.K., France and Germany) regarding their acceptance of commonly used risk-rating factors and their readiness to provide personal information for use in insurers' pricing process. We analyzed their responses to derive strategies for optimal adjustment of pricing practices. The results illustrate that insurers' use of risk-rating factors and consumers' perception of commonly used attributes are strikingly similar. Consumers show highest preference for price-determining factors whose application and impact on the premium they can understand. A stronger weighting of these characteristics in premium calculation can lead to higher profits. However, various risk-rating factors that have not yet been used in pricing insurance have higher approval ratings than some commonly used factors. Insurers would therefore be well advised to check and standardize their pricing models regarding these attributes. In a highly competitive market, customer acceptance of the pricing process and the premium to be paid produces a key competitive advantage. Customer-oriented pricing can make a significant contribution to performance enhancement and strengthening the customer relationship (Murdock and McGrail 1994, p. 2).

Conclusively, the results of this research can be extended in several directions. An important aspect relates to the question of how consumers' willingness to pay can be increased through customer-oriented pricing.

\section{References}

Abraham, K. S.: Efficiency and fairness in insurance risk classification. Va. Law Rev. 71(3), 403-451 (1985)

Actuarial Standards Board: Actuarial Standard of Practice No. 12, Risk Classification (for All Practice Areas). Technical Report, Actuarial Standards Board, Washington, D.C. (2005)

Akerlof, G.: The market for "Lemons": quality uncertainty and the market mechanism. Q. J. Econ. 84(3), 488-500 (1970)

Arrow, K. J.: Uncertainty and the welfare economics of medical care. Am. Econ. Rev. 53(5), 941-973 (1963)

Association of British Insurers (ABI): UK Insurance Key Facts 2013. Technical Report, Association of British Insurers (ABI), London (2013)

Association of British Insurers (ABI), Oxera: The use of gender in insurance pricing: analysing the impact of a potential ban on the use of gender as a rating factor. Technical Report, Association of British Insurers (ABI) and Oxera Consulting, London (2010)

Bain \& Company: Was Versicherungskunden wirklich wollen. Technical Report, Bain \& Company Germany/Switzerland, München/Zürich (2012)

Behrens, G., Fischer, B., Kohler, S., Park, Y., Hollenbeck, A. R., Leitzmann, M. F.: Healthy lifestyle behaviors and decreased risk of mortality in a large prospective study of U.S. women and men. Eur. J. Epidemiol. 28(5), 361-372 (2013)

Belth, J. M.: Calculation of life insurance gross premiums: a suggested modification of the traditional textbook approach. J. Risk Insur. 34(3), 385-396 (1967)

Benston, G. J.: The economics of gender discrimination in employee fringe benefits: manhart revisited. U. Chicago Law Rev. 4(1), 489-542 (1982) 
Benston, G. J.: Discrimination and economic efficiency in employee fringe benefits: a clarification of issues and a response to Professors Brilmayer, Laycock, and Sullivan. U. Chicago Law Rev. 50(1), 250-279 (1983)

Bieck, C., Graf, A., Maas, P.: Trust, transparency and technology_European customers' perspectives on insurance and innovation. Technical Report, IBM Institute for Business Value and Institute of Insurance Economics at the University of St. Gallen, St. Gallen (2008)

Bolderdijk, J. W., Steg, L.: Pay-as-you-drive vehicle insurance as a tool to reduce crash risk: results so far and further potential. In: International Transport Forum at the OECD (ed.) Roundtable on Insurance Costs and Accident Risks, Discussion Paper No. 2011-23, Prepared for the Roundtable on Insurance Costs and Accident Risks (22-23 September 2011, Paris), International Transport Forum at the OECD, Paris (2011)

Bolton, R. N., Drew, J. H.: A multistage model of customers' assessments of service quality and value. J. Consum. Res. 17(4), 375-384 (1991)

Borch, K.: Equilibrium premiums in an insurance market. J. Risk Insur. 51(3), 468-476 (1984)

Borenstein, S.: The economics of costly risk sorting in competitive insurance markets. Int. Rev. Law Econ. 9(1), 25-39 (1989)

Brilmayer, L., Hekeler, R. W., Laycock, D., Sullivan, T. A.: Sex discrimination in employer-sponsored insurance plans: a legal and demographic analysis. U. Chicago Law Rev. 47(3), 505-560 (1979)

Brockett, P. L., MacMinn, R., Carter, M.: Genetic testing, insurance economics, and societal responsibility. North Am. Actuar. J. 3(1), 1-20 (1999)

Burton, S., Lichtenstein, D. R.: Assessing the relationship between perceived and objective price-quality: a replication. Adv. Consum. Res. 17(1), 715-722 (1990)

Buzzacchi, L., Valletti, T.: Strategic price discrimination in compulsory insurance markets. Geneva Risk Insur. Rev. 30(1), 71-97 (2005)

Capgemini, Efma: World Insurance Report 2013. Technical Report, Capgemini and Efma, Paris (2013)

Catellani, B., Hafner, N., Käslin, B.: Kundenloyalität und Kundenbeziehungsmanagement in der Schweizer Assekuranz. Technical Report, Institute of Insurance Economics at the University of St. Gallen, Customer World AG and ValueQuest GmbH, St. Gallen (2004)

CEA Insurers of Europe: CEA Statistics N39: insurance distribution channels in Europe. Technical Report, CEA Insurers of Europe, Brussels (2010)

Christianson, D. J.: Genetic testing: risk classification and adverse selection. J. Insur. Regul. 15(1), 75-79 (1996)

Crocker, K., Snow, A.: The efficiency effects of categorical discrimination in the insurance industry. J. Polit. Econ. 94(2), 321-344 (1986)

Crocker, K. J., Snow, A.: The theory of risk classification. In: Dionne, G. (ed.) Handbook of Insurance, pp. 245-276. Kluwer Academic Publisher, Norwell (2000)

Cunningham, L. F., Gerlach, J., Harper, M. D.: Perceived risk and e-banking services: an analysis from the perspective of the consumer. J. Financ. Serv. Market. 10, 165-178 (2005)

De Wit, G. W.: The politics of rate discrimination: an international perspective. J. Risk Insur. 53(4), 644$661(1986)$

Dodds, W. B., Monroe, K. B.: The effect of brand and price information on subjective product evaluations. Adv. Consum. Res. 12(1), 85-90 (1985)

Doherty, N. A.: Moral hazard and pricing in the U.K. fire insurance market. J. Risk Insur. 47(2),240-257 (1980)

Doherty, N. A.: Is rate classification profitable?. J. Risk Insur. 48(2), 286-295 (1981)

Doherty, N. A.: Stochastic choice in insurance and risk sharing: a reply. J. Financ. 38(3), 1037-1039 (1983)

Durnin, M., Hoy, M., Ruse, M.: Genetic testing and insurance: the complexity of adverse selection. Ethic. Perspect. 19(1), 123-154 (2012)

Edlin, A. S.: Per-mile premiums for auto insurance. NBER Working Paper Series, 6934, 55 (1999)

Erdönmez, M., Gerber, M., Nützenadel, C.: Pricing-Strategien in der Motorfahrzeug-Versicherung. Technical Report, Institute of Insurance Economics at the University of St. Gallen and Solution Providers, St. Gallen (2006)

Ernst \& Young Global Limited: Voice of the customer: time for insurers to rethink their relationshipsglobal consumer insurance survey 2012. Technical Report, Ernst \& Young Global Limited, London (2012)

Etgar, M.: Unfair price discrimination in P-L insurance and the reliance on loss ratios. J. Risk Insur. 42(4), 615-625 (1975)

European Court of Justice (ECJ): Judgement of the Court. Case C-236/09 (2011) 
Farny, D.: Versicherungsbetriebslehre, 5th edn. Verlag Versicherungswirtschaft, Karlsruhe (2011)

Fillenbaum, G. G., Burchett, B. M., Kuchibhatla, M. N., Cohen, H. J., Blazer, D. G.: Effect of cancer screening and desirable health behaviors on functional status, self-rated health, health service use and mortality. J. Am. Geriatr. Soc. 55(1), 66-74 (2007)

Ford, E. S., Zhao, G., Tsai, J., Li, C.: Low-risk lifestyle behaviors and all-cause mortality: findings from the national health and nutrition examination survey III mortality study. Am. J. Public Health 101(10), 1922-1929 (2011)

Gard, J.-C., Eyal, O.: The six steps to pricing power in insurance. Technical Report, The Boston Consulting Group, Paris/London (2012)

Hambrecht, R., Wolf, A., Gielen, S., Linke, A., Hofer, J., Erbs, S., Schoene, N., Schuler, G.: Effect of exercise on coronary endothelial function in patients with coronary artery disease. N. Engl. J. Med. 342(7), 454-460 (2000)

Hedges, B.: Gender discrimination in pension plans: comment. J. Risk Insur. 44(1), 141-144 (1977)

Hickman, J.: Pensions and sex. J. Risk Insur. 50(4), 681-687 (1983)

Homburg, C., Koschate, N., Hoyer, W. D.: Do satisfied customers really pay more? A study of the relationship between customer satisfaction and willingness to pay. J. Market. 69, 84-96 (2005)

Hoy, M.: Categorizing risks in the insurance industry. Q. J. Econ. 97(2), 321-336 (1982)

Hoy, M.: Risk classification and social welfare. Geneva Pap. R. I.-Iss. P. 31(2), 245-269 (2006)

Hoy, M., Lambert, P.: Genetic screening and price discrimination in insurance markets. Geneva Pap. R. I. Theor. 25(2), 103-130 (2000)

IBM Global Business Services: Insurance 2020: innovating beyond old models. Technical Report, IBM Global Business Services, Somers (2006)

Insurance Europe: European insurance-Key facts. Technical Report, Insurance Europe, Brussels (2013a)

Insurance Europe: Total European insurance business 2011. Technical Report, Insurance Europe, Brussels (2013b)

Ippisch, T., Thiesse, F.: Das Pay-as-you-drive (PAYD)-Konzept in der Versicherungswirtschaft. Technical Report, The Mobile and Ubiquitous Computing Lab (M-Lab), St. Gallen/Zürich (2007)

Jannott, E.: Wandel der Vertriebssysteme in der deutschen Versicherungswirtschaft. In: Müller, H., Golz, J.-F., Washausen-Richter, E. (eds.) 100 Jahre materielle Versicherungsaufsicht in Deutschland: 19012001, pp. 551-589. Bundesaufsichtsamt für das Versicherungswesen, Bonn (2001)

Khazzoom, J. D.: Pay-at-the-pump auto insurance: review of criticisms and proposed modification. J. Insur. Regul. 18(4), 448-496 (2000)

Kimball, S. L.: Reverse sex discrimination: manhart. Am. B. Found. Res. J. 4(1), 85-139 (1979)

Laycock, D., Sullivan, T. A.: Sex discrimination as "actuarial equality": a rejoinder to kimball. Am. B. Found. Res. J. 6(1), 221-228 (1981)

Lemaire, J., Park, S., Wang, K.: The use of annual mileage as a rating variable. Working Paper Series Wharton School of the University of Pennsylvania, p. 26 (2012)

Litman, T.: Pay-as-you-drive insurance: recommendations for implementation. Technical Report, Victoria Transport Policy Institute, Victoria (2011a)

Litman, T. A.: Distance-based vehicle insurance feasibility, costs and benefits. Technical Report, Victoria Transport Policy Institute, Victoria (2011b)

Löllgen, H., Bockenhoff, A., Knapp, G.: Physical activity and all-cause mortality: an updated meta-analysis with different intensity categories. Int. J. Sports Med. 30(3), 213-224 (2009)

Löllgen, H., Löllgen, D.: Prävention von Volkskrankheiten: Aus kardiologischer und sportwissenschaftlicher Sicht. In: Schumpelick, V., Vogel, B. (eds.) Volkskrankheiten: Gesundheitliche Herausforderungen in der Wohlstandsgesellschaft, pp. 553-567. Herder, Freiburg i. Br. (2009)

MarketLine: Insurance in France. Technical Report October, MarketLine, Manchester (2012a)

MarketLine: Insurance in Germany. Technical Report October, MarketLine, Manchester (2012b)

MarketLine: Insurance in the United Kingdom. Technical Report October, MarketLine, Manchester (2012c)

Martin, G.: Gender discrimination in pension plans: author's reply. J. Risk Insur. 44(1), 145-149 (1977)

Matzler, K., Würtele, A., Renzl, B.: Dimensions of price satisfaction: a study in the retail banking industry. Int. J. Bank Market. 24(4), 216-231 (2006)

Morris, L. A.: Life Insurance and genetic tests: risks for insurers and society. Health Risk Soc. 12(3), 251-270 (2010)

Murdock, G. W., McGrail, G. R.: Developing a customer-oriented approach to fee setting. National Public Accountant 39(9), 17-24 (1994)

Myers, R.: Gender discrimination in pension plans: further comment. J. Risk Insur. 44(1), 144-145 (1977) 
Organisation for Economic Co-operation and Development: Insurance indicators: total gross premiums. Technical Report, Organisation for Economic Co-operation and Development (OECD), Paris (2012)

Oxera Consulting: Why the use of age and disability matters to consumers and insurers. Technical Report, Oxera Consulting, Oxford (2012)

Pell, J. P., Haw, S., Cobbe, S., Newby, D. E., Pell, A. C. H., Fischbacher, C., McConnachie, A., Pringle, S., Murdoch, D., Dunn, F., Oldroyd, K., MacIntyre, P., O’Rourke, B., Borland, W.: Smoke-free legislation and hospitalizations for acute coronary syndrome. N. Engl. J. Med. 359(5), 482-491 (2008)

Powers, M. R.: Where ignorance is bliss: the "dark corner" of risk classification. J. Risk Financ. 11(4), 353-357 (2010)

RGA, Towers Watson: Produkt-Survey Lebensversicherung 2012/2013. Technical Report, RGA International Reinsurance Company Limited and Towers Watson, Köln (2013)

Rothschild, M., Stiglitz, J.: Equilibrium in competitive insurance markets: an essay on the economics of imperfect information. Q. J. Econ. 90(4), 629-649 (1976)

Schechter, L.: A normative conception of value. In: Progressive Grocer, Executive Report, pp. 12-14. (1984)

Scherer, G., Schmeiser, H.: Assekuranz 2015-Eine Standortbestimmung: Neue Koordinaten im deutschsprachigen Versicherungsmarkt. Technical Report, Accenture and Institute of Insurance Economics at the University of St. Gallen, St. Gallen/Zürich (2010)

Schmeiser, H., Störmer, T., Wagner, J.: Unisex insurance pricing: consumers' perception and market implications. Geneva Pap. R. I.-Iss. P. 39(2), 322-350 (2014)

Schmidt-Gallas, D., Beeck, V.: Das Pricing deutscher Versicherer im internationalen Vergleich. Technical Report, Simon Kucher \& Partners (2007)

Schwarze, R., Wein, T.: Is the market classification of risk always efficient?-Evidence from German third party motor insurance. Ger. Risk Insur. Rev. 1(1), 172-202 (2005)

Seiler, T., Staib, D., Puttaiah, M. D.: Sigma No. 3/2013: World Insurance in 2012. Technical Report, Swiss Re Ltd Economic Research \& Consulting, Zürich (2013)

Shipley, D., Jobber, D.: Integrative pricing via the pricing wheel. Ind. Market. Manag. 30(3), 301-314 (2001)

Simon Kucher \& Partners: Global Pricing Study 2011: Schlechtes Pricing senkt Gewinne um $25 \%$. Technical Report, Simon Kucher \& Partners, Bonn (2011a)

Simon Kucher \& Partners: Pay-per-Use in der Kfz-Versicherung: Wachstumstreiber oder teurer Flop?. Technical Report, Simon-Kucher \& Partners, Frankfurt (2011b)

Simon Kucher \& Partners: Pricing Stresstest 2011. Technical Report, Simon Kucher \& Partners, Bonn (2011c)

Störmer, T., Wagner, J.: A comparison of insurers' usage and consumers' perception of price differentiation factors. Working Papers on Risk Management and Insurance, St. Gallen, 139, 24 (2013)

Teufel, P., Tongson, T. J., Rech, J. E.: Insurance Risk 101. Technical Report, American Academy of Actuaries, Washington, D.C (2001)

Thiery, Y., Van Schoubroeck, C.: Fairness and equality in insurance classification. Geneva Pap. R. I.-Iss. P. 31(2), 190-211 (2006)

Thomas, R. G.: Some novel perspectives on risk classification. Geneva Pap. R. I.-Iss. P. 32(1), 105-132 (2007)

Thomas, R. G.: Loss coverage as a public policy objective for risk classification schemes. J. Risk Insur. 75(4), 997-1018 (2008)

U.S. Supreme Court:City of Los Angeles Department of Water and Power v. Manhart, 435 U.S. 702 (2008). (1978)

U.S. Supreme Court: Arizona Governing Committee for Tax Deferred Annuity and Deferred Com- pensation Plans et al. v. Norris, 103 S. Ct. 3492. (1983)

Venezian, E.: Efficiency and equity in insurance. J. Risk Insur 51(2), 190-204 (1984)

Vickrey, W.: Automobile accidents, tort law, externalities, and insurance: an economist's critique. Law Contemp. Probl. 33(3), 464-487 (1968)

Walters, M. A.: Risk classification standards. Proceedings of the Casualty Actuarial Society LXVIII(129), 1-18. (1981)

Wenzel, T.: Analysis of national pay-as-you-drive insurance systems and other variable driving charges. Technical Report, Lawrence Berkeley Laboratory at the University of California, Berkeley (1995)

Werner, U. Basis for the production of insurance coverage. In: Institute of Insurance Science (ed.) Principles of Insurance Management, pp. 37-73. Karlsruhe Institute of Technology, Karlsruhe (2013)

Williams, A. C. J.: Some economic and legal aspects of insurance rate discrimination. J. Risk Insur. 24(2), 9-23 (1957) 
Wolf, B.: Internationale Unternehmen und nationale Kultur: Ein Vergleich zwischen Großbritannien und Deutschland am Beispiel der Versicherungswirtschaft. Dissertation, Universität Duisburg-Essen (2009)

Zeithaml, V. A. How consumer evaluation processes differ between goods and services. In: J. H. Donnelly, W. R. George (eds.) Marketing of Services, pp. 1986-1990. American Marketing Association, Chicago (1981)

Zeithaml, V. A. (1988) Consumer perceptions of price, quality, and value: a means-end model and synthesis of evidence. J. Marketing 52(July 1988), 2-22. 